\title{
Babesia canis vogeli infection in dogs and ticks in the semiarid region of Pernambuco, Brazil ${ }^{1}$
}

\author{
Andreina C. Araujo ${ }^{2}$, Júlia A.G. Silveira ${ }^{3}$, Sérgio S. Azevedo ${ }^{4}$, Fernanda A. Nieri-Bastos ${ }^{5}$, \\ Múcio F.B. Ribeiro ${ }^{3}$, Marcelo B. Labruna ${ }^{5}$ and Mauricio C. Horta ${ }^{2 *}$
}

\begin{abstract}
Araujo A.C., Silveira J.A.G., Azevedo S.S., Nieri-Bastos F.A., Ribeiro M.F.B., Labruna M.B. \& Horta M.C. 2015. Babesia canis vogeli infection in dogs and ticks in the semiarid region of Pernambuco, Brazil. Pesquisa Veterinária Brasileira 35(5):456-461. Laboratório de Doenças Parasitárias, Universidade Federal do Vale do São Francisco, Rodovia BR-407 Km 12, Lote 543, Projeto de Irrigação Nilo Coelho s/n, C1, Petrolina, PE 56300990, Brazil. E-mail: horta.mc@hotmail.com

This study aimed to report the prevalence of Babesia canis vogeli in dogs and ticks in the urban and rural areas of Petrolina, Pernambuco. Serum and peripheral blood samples of 404 dogs were tested by indirect immunofluorescence assay (IFA) and by blood smears, respectively. The presence of tick infestation was evaluated, and some specimens were submitted to DNA amplification by polymerase chain reaction (PCR). The presence of antibodies anti- $B$. canis vogeli was determinate in $57.9 \%$ (234/404) of dogs. The direct detection of Babesia spp was obtained in $0.5 \%(2 / 404)$ dogs by visualization of intraerythrocytic forms. Infestation by Rhipicephalus sanguineus sensu lato was observed in 54.5\% (220/404) of dogs in both urban and rural areas. DNA of Babesia canis vogeli were obtained by PCR in $6 \%$ individual $(3 / 50)$ and $8.7 \%$ of pool of ticks $(7 / 80)$. The risk factors for the presence of anti-B. canis vogeli antibodies, as determined through the application of logistic regression models $(P<0.05)$, were the following: medium breed size variables $(P<0.001)$; contact with areas of forest $(P=0.021)$; and access on the street $(P=0.046)$. This study describes, for the first time, the confirmation of infection of $B$. canis vogeli in dogs and ticks in the semiarid region of Pernambuco, Brazil.
\end{abstract}

INDEX TERMS: Babesiosis, Rhipicephalus sanguineus, indirect immunofluorescence assay, PCR, Pernambuco.

RESUMO.- [Infecção por Babesia canis vogeli em cães e carrapatos de uma região semiárida de Pernambuco.] Este trabalho objetivou avaliar a prevalência de Babesia ca-

\footnotetext{
${ }^{1}$ Received on January 6, 2015.

Accepted for publication on March 30, 2015.

${ }^{2}$ Laboratório de Doenças Parasitárias, Universidade Federal do Vale do São Francisco (Univasf), Rodovia BR-407 Km 12, Lote 543, Projeto de Irrigação Nilo Coelho s/n, C1, Petrolina, PE 56300-990, Brazil. E-mails: andreinacarvalhoa@hotmail.com; *Corresponding author: horta.mc@hotmail.com

${ }^{3}$ Departamento de Parasitologia, Instituto de Ciências Biológicas, Universidade Federal de Minas Gerais (UFMG), L4 sala 237, Pampulha, Belo Horizonte, MG 31270-910, Brazil. E-mail: juliaags@yahoo.com.br, muciobr@icb.ufmg.br

${ }^{4}$ Unidade Acadêmica de Medicina Veterinária, Centro de Saúde e Tecnologia Rural, Universidade Federal de Campina Grande (UFCG), Av. Universitária s/n, Santa Cecília, Patos, PB 58700970, Brazil. E-mail: sergio@ vps.fmvz.usp.br

${ }^{5}$ Departamento de Medicina Veterinária Preventiva e Saúde Animal, Faculdade de Medicina Veterinária e Zootecnia, Universidade de São Paulo (USP), Av. Prof. Orlando Marques de Paiva 87, Cidade Universitária, São Paulo, SP 05508-270, Brazil. E-mail: fenieri@usp.br; labruna@usp.br
}

nis vogeli em cães e carrapatos de áreas urbanas e rurais do município de Petrolina, Pernambuco, Nordeste do Brasil. Amostras de soro e sangue periférico de 404 cães foram testadas pela Reação de Imunoflorescência Indireta (RIFI), e por esfregaço sanguíneo. A presença de infestação por carrapatos foi avaliada, e alguns espécimes foram submetidos à amplificação do DNA pela Reação em Cadeia pela Polimerase (PCR). A presença de anticorpos anti-B. canis vogeli foi determinada em $57,9 \%$ (234/404) dos cães. A soroprevalência em áreas urbanas e rurais foi 48,5\% e 67,3\%, respectivamente. A detecção direta de Babesia spp foi obtida em $0,5 \%$ dos cães pela visualização de formas intraeritrocitárias. A infestação pelo carrapato Rhipicephalus sanguineus foi observada em 54,5\% (220/404) dos cães. DNA de Babesia canis vogeli obtido pela PCR foi 6\% (3/50) em carrapatos processados individualmente e 8,7\% (7/80) em pools. Os fatores de risco para presença de anticorpos anti$B$. canis vogeli utilizando modelo de regressão logística $(P$ $<0,05)$ foram porte médio $(\mathrm{P}<0,001)$, contato com áreas 
de floresta $(P=0,021)$, e acesso dos cães à rua $(P=0,046)$. Este estudo descreve pela primeira vez a confirmação da infecção de Babesia canis infectando cães e carrapatos em uma região semiárida de Pernambuco, Brasil.

TERMOS DE INDEXAÇÃO: Babesiose, Rhipicephalus sanguineus, imunofluorescência indireta, PCR, Pernambuco.

\section{INTRODUCTION}

Canine babesiosis is an emerging disease of large veterinary importance worldwide (Jefferies et al. 2007), caused by intraerythrocytic protozoans of the genus Babesia. The main species that infect dogs are B. canis and B. gibsoni transmitted by ticks of different genus and species (Dantas-Torres \& Figueredo 2006).

The disease in Brazil is predominantly caused by $\mathrm{B}$. $\mathrm{Ca}$ nis vogeli (Dantas-Torres 2008a), presenting prevalence ranging from $18.8 \%$ to $73.3 \%$ (Trapp et al. 2006, Maia et al. 2007, Furuta et al. 2009, Spolidorio et al. 2010); associated with high incidence of tick vector Rhipicephalus sanguineus (Dantas-Torres 2008b), whose prevalence and intensity of infestation have increased in dogs (Labruna 2004).

The diagnosis can be done by identification of parasites based on the size and morphology of intraerythrocytic forms in peripheral blood smears (Passos et al. 2005, Ungar de Sá et al. 2007). Serological tests are broadly used in the diagnosis of this disease, as the Indirect Immunofluorescence Assay (IFA) (Boozer \& Macintire 2003) are useful in the identification of asymptomatic carriers animals and diagnose chronic infections, when the level of parasitemia is generally low or undetectable in blood smear (Furuta et al. 2009). Nevertheless, IFA indicates the exposure to the agent, without providing information regarding the current stage of infection (Dantas-Torres \& Figueredo 2006). Therefore, molecular techniques, such as the Polymerase Chain Reaction (PCR), have been applied, showing that detection and identification of the infections with Babesia spp was efficient (Birkenheuer et al. 2004, Passos et al. 2005).

The canine babesiosis has a cosmopolitan distribution, however the prevalence of antibodies anti-B. canis vogeli in the northeastern region are scarce. In Pernambuco state, few studies have been conducted in the Atlantic Forest areas (Ramos et al. 2010), whereas no information about canine babesiosis in small and medium cities, more specifically in the semiarid region, has been published.

This study aimed to determine the prevalence of Babesia spp. in dogs and ticks of urban and rural areas of the municipality of Petrolina, Pernambuco state, by detection of parasites in blood smears, detection of antibodies by IFA, and detection of DNA of Babesia spp. in ticks by PCR, analyzing the risk factors associated with infection by the pathogen in this region.

\section{MATERIALS AND METHODS}

The study was conducted in urban and rural areas of the municipality of Petrolina, Pernambuco state (S 9²3'55", W 40³0'03"), located in the semiarid region of Northeastern Brazil. Five neighborhoods were chosen randomly within each urban (Areia Branca, Gercino Coelho, José e Maria, São Gonçalo, Vila Eduardo) and rural area (Maria Tereza, N5, N6, N10, Nova Descoberta). Ac- cording to the Brazilian Institute of Geography and Statistics, the municipality has a population of 294,081 inhabitants; occupying an area of $4,558,537 \mathrm{~km}^{2}$, which is covered by the polygon of droughts (IBGE 2010). However, there's no data about the canine population in this area.

From August 2011 to January 2012, 404 dogs were evaluated (202 from urban areas and 202 from rural areas), varying gender, breed and age. The number of animals studied was based on an estimated prevalence of $50 \%$, with a confidence level of $95 \%$ and a margin of error of $7 \%$. Blood was collected by cephalic venipuncture. About $4 \mathrm{~mL}$ of blood was collected from each animal, then the blood was placed into tubes without anticoagulant and maintained at room temperature until the retraction of the clot, and serum was obtained by centrifugation. The samples were stored at $-20^{\circ} \mathrm{C}$.

All dogs were inspected for the presence of ticks, which, once found, were removed with the aid of anatomical tweezers, placed in tubes containing $70^{\circ}$ ethanol solution and identified under a stereomicroscope, according to morphological key provided by Aragão \& Fonseca (1961).

The smears were made with blood taken from the ear margin capillary bed, then air-dried and stained $\left(\right.$ Renylab $\left.^{\circledR}\right)$, and the entire slides were observed under optical microscope immersion $(1,000 x)$.

Immunofluorescence Assay (IFA) using antigens of B. canis vogeli obtained from a splenectomized dog that was experimentally infected with isolate from Belo Horizonte-Minas Gerais (Bicalho et al. 2002). The antigen was produced following the methodology described by IICA (1984) with modifications. Briefly, IFA was performed with $5 \mu \mathrm{L}$ of serum samples (using a dilution of 1:40) incubated at $37^{\circ} \mathrm{C}$ for 30 minutes in slides of blood smears containing parasitized erythrocytes and washed three times for 3 minutes in $1 \mathrm{x}$ phosphate buffered saline (PBS, pH 7.2) and finally washed twice with distilled water. Subsequently, each well was added with anti-dog IgG conjugated marked with fluorescein isothiocyanate (FITC - Bethyl Laboratories, Montgomery, TX, USA) diluted 1:150 in Evans blue (1:50 in Tween PBS). Slides were then incubated at $37^{\circ} \mathrm{C}$ for 30 minutes, washed as previously described, allowed to air dry and, subsequently, examined in microscope with fluorescent light source (Olympus Corporation, Tokyo, Japan) at 20- and 40-x magnification, being considered positive reactions with fluorescence around the parasites in samples of serum titers of 40 . The reactions were performed at the Laboratory of Veterinary Protozoology, Department of Parasitology, Institute of Biological Sciences, Federal University of Minas Gerais. The positive control comprised appropriately diluted serum derived from a Brazilian dog that was unambiguously seropositive for $B$. canis, while the negative control consisted of a serum sample from a negative dog (samples were further diluted until 1:640).

A total of 370 ticks were randomly separated and 50 were tested individually and 320 in pools of 4 ticks. The entire tick samples were washed in TE (10mM Tris HCl, $1 \mathrm{mM}$ EDTA, pH 8.0) according Horta et al. (2007) and subjected to DNA extraction using the Wizard ${ }^{\circledR}$ Genomic DNA Purification commercial kit (Promega, Madison, USA), according the manufacturer's instructions, to a final volume of $50 \mu \mathrm{L}$ and $75 \mu \mathrm{L}$ for individual ticks and pools, respectively. The eluted DNA was kept at $-20^{\circ} \mathrm{C}$ before PCR amplification.

For the Polymerase Chain Reaction (PCR) primers for amplification of DNA fragments of 551 base pairs of the 18S rRNA gene of Babesia were used according to Almeida (2011): BAB143-167 (5'-CCG TGC TAA TTG TAG GGC TAA TAC A-3') and BAB694-667 (5'-GCT TGA AAC ACT CTA RTT TCT CAA AG-3'). The PCR mix was prepared for a final volume of $25 \mu \mathrm{L}$ water-solution containing $1 \times$ PCR buffer (Invitrogen, Carlsbad, USA); $1.5 \mathrm{mM} \mathrm{MgCl}_{2}$ 
(Invitrogen, Carlsbad, USA); 0.2 mM dNTPs (GE Healthcare, Buckinghamshire, England); 10 pM each primer; 0.25 U of Taq DNA polymerase (Invitrogen, Carlsbad, USA) and $5 \mu \mathrm{L}$ of DNA sample. Amplification was performed in a thermocycler (Biocycler ${ }^{\circledR}$ ), consisting of an initial denaturation for 5 minutes at $95^{\circ} \mathrm{C}$, and 35 repetitive cycles of 30 seconds at $95^{\circ} \mathrm{C}, 30$ seconds at $58^{\circ} \mathrm{C}$, and 30 seconds at $72^{\circ} \mathrm{C}$, followed by a 7 -minute final extension period at $72^{\circ} \mathrm{C}$.

The amplification products obtained were subjected to electrophoresis in 1.5\% agarose gel (Invitrogen, Carlsbad, CA), stained with ethidium bromide and visualized under UV transilluminator. Amplicons of the expected size were purified with ExoSap (GE Healthcare Pittsburgh, PA) and sequenced in an automatic sequencer (Applied Biosystems/PerkinElmer, model ABI Prism 3500 Genetic, Foster City, CA), according to the manufacturer's protocol. Partial sequences obtained were submitted to BLAST analysis (Altschul et al. 1990) to determine the closest similarities to corresponding sequences.

For each sampled dog, a questionnaire was applied to the dog owner with the purpose of gaining information about independent variables that could be associated with seroreactivity to $\mathrm{Ba}$ besia spp (dependent variables).

Risk factor analysis was performed in two steps: univariate and multivariate analysis. Univariate analysis was performed using the chi-square test or Fisher's exact test, and those variables that presented $\mathrm{p} \leq 0.20$ were used for multiple logistic regression. The multivariate analysis was then performed, using the stepwise forward method (Hosmer \& Emeshow 2000). The significance level in multivariate analysis was $5 \%$. The tests were performed using the SPSS for Windows software package, version 13.0.

The study was approved by the Ethics in Human and Animal Studies at the Federal University of Valley do São Francisco under protocol number 29041107.

\section{RESULTS}

The tick infestation was found in $54.5 \%$ (220/404) of the dogs. Rural dogs developed a higher percentage of tick infestation $61.4 \%(124 / 202)$, compared with the dogs in urban areas $47.5 \%(96 / 202)$. A total of 1,511 ticks were collected (70 nymphs, 655 males, and 786 females); in both urban $(\mathrm{n}=652)$ and rural $(\mathrm{n}=859)$ areas. All ticks $(100 \%)$ were identified as Rhipicephalus sanguineus (Table 1).

Intraerythrocytic forms for Babesia spp. were observed in only two samples $(0.5 \%)$ from rural areas, by microscopic analysis of blood smears.

Anti-B. canis vogeli antibodies were detected in $57.9 \%$ (234/404) of dogs by IFA. The seroprevalence in urban areas and rural areas were $48.5 \%(98 / 202)$ and $67.3 \%$, (136/202), respectively.

DNA of Babesia spp. was determinate by PCR in $6 \%$ of individual adult ticks (3/50); and in $8.7 \%$ of pools $(7 / 80)$.
All positive individual ticks were from rural areas; and all positive pools were from urban areas. All samples submitted to DNA sequencing showed identical sequences $100 \%$ identical with Babesia canis vogeli $18 \mathrm{~S}$ ribosomal RNA gene, partial sequence (GenBank KJ494656.1).

In the univariate analysis, variables area, breed, age, breed size, street access, contact with forest/caatinga, presence of ticks and veterinary care were associated $(P<0.20)$ with the prevalence of $B$. canis vogeli and then were selected for the multivariate analysis (Table 2). As shown in Table 3 , when these independent variables were subjected to the multivariate analysis, the following were identified as risk factors for canine babesiosis, significantly associated with the rate of antibodies to Babesia canis vogeli : medium breed size (OR=2.98; $P<0.001)$, contact with areas of forest (Caatinga biome) $(\mathrm{OR}=2.22 ; \mathrm{P}=0.021)$, access to street dogs $(\mathrm{OR}=1.51 ; \mathrm{P}=0.046)$.

\section{DISCUSSION}

In the present study the tick infestation was observed in $54.5 \%$ of dogs. Rural dogs showed a higher percentage of infestation (56.3\%), when compared with urban rural dogs (43.5\%). Although the Rhipicephalus sanguineus is often found in urban areas (Labruna \& Pereira 2001), this tick infestation in rural dogs has also been verified (Szabó et al. 2001, Shimada et al. 2003, O'Dwyer et al. 2009).

Higher prevalence of $R$. sanguineus in rural dogs was also observed by Labruna et al. (2001) in a study of dogs from northern Paraná, although their frequency was lower compared to previous studies carried out in urban areas. The behavior of the dogs, and the rest area in the same place would make this tick species become established in rural areas. High prevalence of $R$. sanguineus in a rural environment of Petrolina, Pernambuco, could be justified by the lifestyle of these dogs, once the great majority was created semi-confined, and having their resting places along the residences of their owners, by facilitating parasitism of this species.

In the microscopic analysis of blood smears, piriform intraerythrocytic forms for Babesia spp were observed in only two samples $(0.5 \%)$ of dogs from the rural area. This low parasitism, found in blood smears, is in accordance with the findings of Guimarães et al. (2004) and Miranda et al. (2008) in dogs in the city of Goytacazes, state of Rio de Janeiro, considered enzootic for canine babesiosis; and of O'Dwyer et al. (2009) in dogs from rural areas of the state of São Paulo. The diagnosis by blood smear has a good specificity, but low sensitivity; committing to early stages of

Table 1. Percentage by area of tick infestation, presence of intraerythrocytic forms Babesia spp in blood smears seropositivity and detection of DNA of Babesia spp in individual and pools of ticks infesting dogs from the urban and rural areas of semiarid region of Pernambuco, Brazil

\begin{tabular}{lcccc}
\hline Area & $\begin{array}{c}\text { \% tick } \\
\text { infestation } \\
\text { (positive/total) }\end{array}$ & $\begin{array}{c}\text { \% blood } \\
\text { smears } \\
\text { (positive/total) }\end{array}$ & $\begin{array}{c}\text { \% IFA } \\
\text { (positive/total) }\end{array}$ & $\begin{array}{c}\text { \% Babesia spp. DNA in ticks: } \\
\text { individual (positive/total); } \\
\text { pool (positive/total) }\end{array}$ \\
\hline Urban & $47.5(96 / 202)$ & $0(0 / 202)$ & $48.5(98 / 202)$ & $0(0 / 50) ; 8.7(7 / 80)$ \\
Rural & $61.4(124 / 202)$ & $0.5(1 / 202)$ & $67.3(136 / 202)$ & $6.0(3 / 50) ; 0(0 / 80)$ \\
Total & $54.5(220 / 404)$ & $0.2(1 / 404)$ & $57.9(234 / 404)$ & $3.0(3 / 100) ; 4.4(7 / 160)$
\end{tabular}


Table 2. Univariate analysis for risk factors associated with Babesia canis vogeli infection in the semiarid region of Pernambuco, Brazil

\begin{tabular}{|c|c|c|c|c|}
\hline $\begin{array}{l}\text { Independent } \\
\text { variables }\end{array}$ & Category & $\begin{array}{l}\text { Total number } \\
\text { of dogs }\end{array}$ & $\begin{array}{c}\text { Positives } \\
\text { (\%) }\end{array}$ & $P$ \\
\hline \multirow[t]{2}{*}{ Area } & Rural & 202 & $136(67,3)$ & $<0,001^{\prime}$ \\
\hline & Urban & 202 & $98(48,5)$ & \\
\hline \multirow[t]{2}{*}{ Breed } & Purebred & 77 & $31(40,3)$ & $0,001^{*}$ \\
\hline & Mixed-breed & 327 & $203(62,1)$ & \\
\hline \multirow[t]{4}{*}{ Age (years) } & $<1$ & 84 & $37(44,0)$ & $0,006^{*}$ \\
\hline & $1-3$ & 194 & $121(62,4)$ & \\
\hline & $3-8$ & 110 & $70(63,6)$ & \\
\hline & $>8$ & 16 & $6(37,5)$ & \\
\hline \multirow[t]{2}{*}{ Gender } & Female & 142 & $80(56,3)$ & 0,712 \\
\hline & Male & 262 & $154(58,8)$ & \\
\hline \multirow[t]{3}{*}{ Breed size } & Small & 125 & $54(43,2)$ & $<0,001^{\prime}$ \\
\hline & Medium & 212 & $149(70,3)$ & \\
\hline & Large & 67 & $31(46,3)$ & \\
\hline \multirow[t]{2}{*}{ Street access } & No & 179 & $92(51,4)$ & $0,023^{*}$ \\
\hline & Yes & 225 & $142(63,1)$ & \\
\hline Contact with & No & 122 & $69(56,6)$ & 0,798 \\
\hline other animals & Yes & 282 & $165(58,5)$ & \\
\hline \multirow{2}{*}{$\begin{array}{l}\text { Contact with forest / } \\
\text { caatinga }\end{array}$} & No & 350 & $193(55,1)$ & $0,006^{*}$ \\
\hline & Yes & 54 & $41(75,9)$ & \\
\hline \multirow[t]{2}{*}{ Historical tick } & No & 78 & $49(62,8)$ & 0,396 \\
\hline & Yes & 326 & $185(56,7)$ & \\
\hline \multirow[t]{2}{*}{ Presence of ticks } & No & 184 & $99(53,8)$ & $0,152^{*}$ \\
\hline & Yes & 220 & $135(61,4)$ & \\
\hline \multirow[t]{2}{*}{ Veterinary care } & No & 307 & $188(61,2)$ & $0,022^{*}$ \\
\hline & Yes & 97 & $46(47,4)$ & \\
\hline \multirow[t]{4}{*}{ Use of acaricide } & No use & 181 & $112(61,9)$ & 0,204 \\
\hline & Only animal & 173 & $91(52,6)$ & \\
\hline & $\begin{array}{c}\text { Animal + } \\
\text { environment }\end{array}$ & 47 & $30(63,8)$ & \\
\hline & $\begin{array}{c}\text { Only } \\
\text { environment }\end{array}$ & 3 & $1(33,3)$ & \\
\hline
\end{tabular}

* Variables selected for the multivariate analysis $(\mathrm{P}<0.20)$.

Table 3. Risk factors associated with Babesia canis vogeli infection in dogs of the semiarid region of Pernambuco, Brazil

\begin{tabular}{lcc}
\hline \multicolumn{1}{c}{ Risk factor } & Odds ratio $(95 \% \mathrm{CI})$ & $P$ \\
\hline Medium breed size & $2.98(1.87-4.74)$ & $<0.001$ \\
Contact with forest /caatinga & $2.22(1.13-4.37)$ & 0.021 \\
Street access & $1.56(1.01-2.41)$ & 0.046
\end{tabular}

disease, where it has a high level of parasitemia, with false negative results under low parasitemia (Krause et al. 1996, Guimarães et al. 2004, Passos et al. 2005).

Detection of anti-B. canis vogeli antibodies occurred in $57.9 \%$ of the analyzed dogs; $48.5 \%$ in dogs of the urban area and $67.3 \%$ of rural area. Guimarães et al. (2009) found seropositivity to IFA in $73.3 \%$ dogs from the municipality of Lavras, state of Minas Gerais. However, a lower prevalence $(18.8 \%)$ was determinate in a canine population in a semiarid area of Porteirinha, Minas Gerais, which has climatic conditions similar to those of the present study (Maia et al. 2007).

Babesia canis is considered endemic in urban areas with high tick infestation of dogs, (Passos et al. 2005), but less frequent in rural areas. The present study, which analyzed dogs who live in rural areas, indicated a seropositivity higher than that observed by Costa-Júnior et al. (2009) for three rural municipalities of Minas Gerais, obtaining a frequency of $28.7 \%$. Vieira et al. (2013) had a higher prevalence $(60.3 \%)$ of anti-B. canis vogeli antibodies in dogs from urban areas of the State of Paraná, which were 3.1 times more likely to acquire anti-B. canis vogeli antibodies than dogs from rural areas. However, in this study, the dogs from rural areas had a higher prevalence of antibodies in relation to dogs in urban areas, which may be justified by the high prevalence of the tick vector, $R$. sanguineus in dogs from rural areas.

The racial pattern, age and mixed breed animals (SRD) showed higher prevalence of presence of $B$. canis vogeli antibodies, as also reported by Maia et al. (2007). These are more likely to acquire the infection by Babesia spp compared to animals of breed, since these are usually raised in confinement, more restricted environments, with little contact with other animals and external environments, thus reducing exposure to vector. Dogs over one year of age have a higher probability of seroconversion, with a higher chance of acquiring tick infestation and consequently a greater chance of acquiring the disease, becoming chronically infected (Ribeiro et al. 1990, Solano-Gallego et al. 2008).

The multivariate analysis showed that dogs of medium breed size were 2.9 times more likely to acquire anti-Babesia canis vogeli antibodies than dogs of the small and large breed size. Access on the street and contact with the dogs with areas of forest (Caatinga) were identified as risk factors for canine babesiosis. These results indicate that the tick vector of $B$. canis vogeli in the study region prefers to live in rural areas, especially in areas with vegetation (forest, caatinga). Additionally, univariate analyses indicated a significant association $(P<0.20)$ of $B$. canis vogeli seroreactivity with dogs living in rural areas and with dogs mixed breed animals (Table 2).

Gender, breed, and age were not associated with the risk of seropositivity amongst the canine population, a finding that is in agreement with of the epidemiological studies on canine babesiosis (Ribeiro et al. 1990, Maia et al. 2007, Costa-Junior et al. 2009).

Detection of Babesia infection in ticks has been widely used in epidemiological studies in various countries (Inokuma et al. 2003, Matjila et al. 2005, M'Ghirbi \& Bouattour 2008, Majláthová et al. 2011). However, in Brazil, few studies have been performed and little is known about the aspects of infection with Babesia spp. in ticks, being unprecedented in the municipality of Petrolina, PE. Silva et al. (2012) obtained a prevalence of $2.6 \% R$. sanguineus infected with $B$. canis vogeli in a study conducted in ticks from dogs from rural and urban areas of western region of Maranhão, lower than the one obtained in this study. M'Ghirbi \& Bouattour (2008) obtained a prevalence of $0.6 \%$ in Tunisia. Higher prevalence was found in $35.6 \%$ ticks in Slovakia (Majláthová et al. 2011).

DNA of B. canis vogeli was observed in $6 \%$ of individual ticks and $8.7 \%$ of pools of ticks. Some seronegative dogs (57.1\%) were infesting by positive ticks. These ticks were, probably, collected from dogs before the inoculation of the agent by ticks, which requires an average three days of blood feeding for transmission, or because the diagnosis by IFA be compromised the initial stage of occurring disease 
because the parasite appears in the blood before there is a detectable antibody level.

Although the municipality of Petrolina, Pernambuco presents favorable climatic conditions for the development of the $R$. sanguineus, the dynamics of tick populations depends on climatic conditions, thus affecting the transmission of Babesia and hence its maintenance in nature (Friedhoff 1988). Considering the hematophagous habitat, ticks have blood of their hosts and positive PCR results in the possibility of tick infection or infected dog. However, it provides information on the prevalence of these agents in the canine population of the region (Inokuma et al. 2003).

\section{CONCLUSIONS}

The presence of canine babesiosis was confirmed in both urban and rural areas of the municipality of Petrolina, Pernambuco, by detection of antibodies anti-Babesia canis in canine sera; and detection of Babesia canis vogeli in ticks infesting dogs.

The risk factors for the presence of anti-B. canis vogeli antibodies were medium breed size variables; contact with areas of forest; and access to the street.

This study describes, for the first time, the confirmation of infection of Babesia canis vogeli in dogs and ticks in the semiarid region of Pernambuco.

Acknowledgements.- The authors are grateful to Fundação de Amparo à Pesquisa do Estado de Pernambuco (FACEPE APQ-1174-5.05/10) and to Conselho Nacional de Desenvolvimento Científico e Tecnológico (CNPq) for financial support.

\section{REFERENCES}

Almeida A.P. 2011. Pesquisa de Rickettsia, Ehrlichia, Anaplasma, Babesia, Hepatozoon e Leishmania em Cachorro-do-mato (Cerdocyon thous) de vida livre do Estado do Espírito Santo. Dissertação de Mestrado em Epidemiologia Experimental Aplicada, Universidade de São Paulo, São Paulo, SP. 80p.

Altschul S.F., Gish W., Miller W., Myers E.W. \& Lipman D.J. 1990. Basic local alignment search tool. J. Mol. Biol. 215:403-410.

Aragão H.B. \& Fonseca F. 1961. Notas de Ixodologia. VIII. Lista e chave para os representantes da fauna ixodológica brasileira. Mem. Inst. Oswaldo Cruz 59:115-129.

Bicalho K.A., Passos L.M.F. \& Ribeiro M.F.B. 2002. Infecção experimental de cães com amostras de Babesia canis isoladas em Minas Gerais. Arq. Bras. Med. Vet. Zootec. 54:546-548.

Birkenheuer A.J., Neel J., Ruslander D., Levy M.G. \& Breitschwerdt E.B. 2004. Detection and molecular characterization of a novel large Babesia species in a dog. Vet. Parasitol. 124:151-160.

Boozer A.L. \& MacIntire D.K. 2003. Canine babesiosis. Vet. Clin. North Am., Small Anim. Pract. 33:885-904.

Costa-Júnior L.M., Ribeiro M.F., Rembeck K., Rabelo E.M., Zahler-Rinder M., Hirzmann, J., Pfister K. \& Passos L.M.F. 2009. Canine babesiosis caused by Babesia canis vogeli in rural areas of the State of Minas Gerais, Brazil and factors associated with its seroprevalence. Res. Vet. Sci. 86:257-260.

Dantas-Torres F. \& Figueredo L.A. 2006. Canine babesiosis: a Brazilian perspective. Vet. Parasitol. 141:197-203.

Dantas-Torres F. 2008a. Causative agents of canine babesiosis in Brazil. Prev. Vet. Med. 83:210-211.

Dantas-Torres F. 2008b. Canine vector-borne diseases in Brazil. Parasit. Vectors 1:1-25.

Friedhoff K.T. 1988. Transmission of Babesia, p.23-52. In: Ristic M. (Ed.), Babesiosis of Domestic Animals and Man. CRC Press, Boca Raton.
Furuta P.I., Oliveira T.M., Teixeira M.C., Rocha A.G., Machado R.Z. \& Tinucci-Costa M.G. 2009. Comparison between a soluble antigen-based ELISA and IFAT in detecting antibodies against Babesia canis in dogs. Revta Bras. Parasitol. Vet. 18:41-45.

Guimarães A.M., Rocha C.M.B.M., Oliveira T.M.F.S., Rosado I.R., Morais L.G. \& Santos R.R.D. 2009. Fatores associados à soropositividade para $\mathrm{Ba}$ besia, Toxoplasma, Neospora e Leishmania em cães atendidos em nove clínicas veterinárias do município de Lavras, MG. Revta Bras. Parasitol. Vet. 18:49-53.

Guimarães J.C., Albernaz A.P., Machado J.A., Melo Junior O.A. \& Garcia L.N.N. 2004. Aspectos clínico-laboratoriais da babesiose canina na cidade de Campos do Goytacazes, RJ. Revta Bras. Parasitol. Vet. 13:229.

Horta M.C., Labruna M.B., Pinter A., Linardi P.M. \& Schumaker T.T.S. 2007. Rickettsia infection in five areas of the state of São Paulo, Brazil. Mem. Inst. Oswaldo Cruz 102:793-801.

Hosmer D.W. \& Lemeshow S. 2000. Applied logistic regression. John Wiley and Sons, New York. 375p.

IBGE 2010. Censo Demográfico 2010. Instituto Brasileiro de Geografia e Estatística, Brasília.

IICA 1984. Técnicas para el Diagnóstico de Babesiosis y Anaplasmosis Bovinas. Instituto Interamericano de Cooporacion para la Agricultura, San José. Serie Salud Animal. n.8.

Inokuma H., Yoshizaki Y., Shimada Y., Sakata Y., Okuda M. \& Onishil T. 2003. Epidemiological survey of Babesia species in Japan performed with specimens from ticks collected from dogs and detection of new Babesia DNA closely related to Babesia odocoilei and Babesia divergens DNA. J. Clin. Microbiol. 41:3494-3498.

Jefferies R., Ryan U.M. \& Irwin P.J. 2007. PCR-RFLP for the detection and differentiation of the canine piroplasm species and its use with filter paper-based technologies. Vet. Parasitol. 144:20-27.

Krause P.J., Telford S.I.I.I, Spielman A., Ryan R., Magera J., Rajan T.V., Christianson D., Alberghini T.V., Bow L. \& Persing D. 1996. Comparison of PCR with blood smear and inoculation of small animals for diagnosis of Babesia parasitemia. J. Clin. Microbiol. 34:2791-2794.

Labruna M.B. \& Pereira M. 2001. Carrapato em cães no Brasil. Clin. Vet. 30:4-32.

Labruna M.B., Souza S.L.P., Guimarães Junior J.S., Pacheco R.C., Pinter A. \& Gennari S.M. 2001. Prevalência de carrapatos em cães de áreas rurais da região norte do Estado do Paraná. Arq. Bras. Med. Vet. Zootec. 53:553556.

Labruna M.B. 2004. Biologia-Ecologia de Rhipicephalus sanguineus (Acari: Ixodidae). Revta Bras. Parasitol. Vet. 13:S1.

M'GhirbI Y. \& Bouattour A. 2008. Detection and molecular characterization of Babesia canis vogeli from naturally infected dogs and Rhipicephalus sanguineus ticks in Tunisia. Vet. Parasitol. 152:1-7.

Maia M.G., Costa R.T., Haddad J.P., Passos L.M. \& Ribeiro M.F. 2007. Epidemiological aspects of canine babesiosis in the semiarid area of the state of Minas Gerais, Brazil. Prev. Vet. Med. 79:155-162.

Majláthová V., Majláth I., Vichová B., Gul'ová I., Derdáková M. \& Sesztáková E. 2011. Polymerase chain reaction Confirmation of Babesia canis canis and Anaplasma phagocytophilum in Dogs Suspected of Babesiosis in Slovakia. Vector Borne and Zoonotic Diseases 11(11):1447-1451.

Matjila P.T., Nijhof A.M., Taoufik A., Houwers D., Teske E. \& Penzhorn B.L. 2005. Autochthonous canine babesiosis in The Netherlands. Vet. Parasitol. 131:23-29.

Miranda F.J.B., Albemaz A.P., Melo Junior O.A. \& Machado J.A. 2008. Frequência de cães infectados por Babesia spp. em Campos dos Goytacazes, RJ. Ciênc. Anim. Bras. 9:238-241.

O’Dwyer L.H., Lopes V.V.A., Rubini A.S., Paduan K.S. \& Ribolla P.E.M. 2009. Babesia spp. infection in dogs from rural areas of São Paulo State, Brazil. Revta Bras. Parasitol. Vet. 18:23-26.

Passos L.M.F., Geiger S.M., Ribeiro M.F.B., Pfister K. \& Zahler-Rinder M. 2005. First molecular detection of Babesia vogeli in dogs from Brazil. Vet. Parasitol. 127:81-85.

Ramos R.A., Ramos C., Araújo F., Oliveira I., Pimentel D., Galindo M., Santana M., Rosas E., Faustino M. \& Alves L.C. 2010. Molecular survey and ge- 
netic characterization of tick-borne pathogens in dogs in metropolitan Recife, north-eastern Brazil. Parasitol. Res. 107:1115-1120.

Ribeiro M.F.B., Passos L.M.F., Lima J.D. \& Guimarães A.M. 1990. Frequency of anti-Babesia canis antibodies in dogs, in Belo Horizonte, Minas Gerais. Arq. Bras. Med. Vet. Zootec. 42:511-517.

Shimada Y., Beppu T., Inokuma H., Okuda M. \& Onishi T. 2003. Ixodid tick species recovered from domestic dogs in Japan. Med. Vet. Entomol. 17:38-45.

Silva B.A., Costa A.P., De Sá J.C., Costa F.B., Santos A.C.G. \& Guerra R.M.S.N.C. 2012. Detecção molecular de Babesia canis vogeli em cães e em Rhipicephalus sanguineus na mesorregião do Oeste Maranhense, Nordeste Brasileiro. Ciênc. Anim. Bras. 13:388-395.

Solano-Gallego L., Trotta M., Carli E., Carcy B., Caldin M. \& Furlanello T. 2008. Babesia canis canis and Babesia canis vogeli clinicopathological findings and DNA detection by means of PCR-RFLP in blood from Italian dogs suspected of tick-borne disease. Vet. Parasitol. 157:211-221.

Spolidorio M.G., Labruna M.B., Machado R.Z., Moraes-Filho J., Zago A.M., Donatele D.M., Pinheiro S.R., Silveira I., Caliari K.M. \& Yoshinari N.H.
2010. Survey for tick-borne zoonoses in the state of Espírito Santo, southeastern Brazil. Am. J. Trop. Med. Hyg. 83:201-206.

Szabó M.P.J., Cunha M., Santos A.P. \& Vicentini F. 2001. Ticks (Acari: Ixodidae) associated with domestic dogs in Franca region, São Paulo, Brazil. Exp. Appl. Acarol. 25:909-916.

Trapp S.M., Dagnone A.S., Vidotto O., Freire R.L., Amude A.M. \& Morais H.S. 2006. Seroepidemiology of canine babesiosis and ehrlichiosis in a hospital population. Vet. Parasitol. 140:223-230.

Ungar de Sá M.F.M., Ungar de Sá J.E., Bittencourt D.V.V., Bispo A.C., Régis A.M.M., Souza Filho N.J., Gomes Neto C.M.B., Souza B.M.P.S., Bittencourt T.C.C. \& Franke C.R. 2007. Estudo retrospectivo (1991-2005) dos casos de babesiose canina na cidade de Salvador e Região Metropolitana, Bahia. Revta Bras. Saúde Prod Anim. 8:178-183.

Vieira T.S.W.J., Vieira R.F.C., Nascimento D.A.G., Tamekuni K., Toledo R.S., Chandrashekar R., Marcondes M., Biondo A.W. \& Vidotto O. 2013. Serosurvey of tick-borne pathogens in dogs from urban and rural areas of Parana State, Brazil. Revta Bras. Parasitol. Vet. 22:104-109. 